\title{
Comparative Study of Caudal Bupivacaine and Bupivacaine with Clonidine in Infra Umbilical Surgeries in Children
}

\author{
Swetha J Gouda ${ }^{1}$, P.V. Margi' \\ ${ }^{1}$ Associate Professor, Department of Anesthesia, Gadag Institute of Medical Sciences, Gadag, India.
}

\section{Abstract}

Background: Caudal epidural analgesia is one of the most commonly performed regional blocks in paediatric anaesthesia for intra and postoperative analgesia. Addition of opioids like morphine, fentanyl is associated with side effects like respiratory depression, urinary retention, etc. Clonidine, an $\alpha 2$ agonist is known for its analgesic effects with lesser side effects. Hence, this study was conducted to know the efficacy and safety of addition of clonidine to bupivacaine in a single shot caudal block in children. Subjects and Methods: This study was conducted among 60 children in the age group of 5-10 years coming for various elective infraumbilical surgical procedures. They were divided into two groups of 30 each. Group A received caudal $0.25 \%$ bupivacaine $(1 \mathrm{ml} / \mathrm{kg})$ and group B received caudal $0.25 \%$ bupivacaine $(1 \mathrm{ml} / \mathrm{kg})$ with clonidine $(1.5 \mu \mathrm{g} / \mathrm{kg})$. The various parameters studied were hemodynamic changes, duration of analgesia and incidence of side effects. Results: The groups were similar in age, sex and weight. The hemodynamic parameters like heart rate, blood pressure, respiratory rate were also similar between the two groups after administering caudal block. The mean duration of analgesia in group B (433.5 \pm 60 min) was significantly longer ( $p<0.05)$ than group A $(250.33 \pm 41 \mathrm{~min})$. Conclusion: This study showed that the addition of clonidine in the dose of $1.5 \mu \mathrm{g} / \mathrm{kg}$ to $0.25 \%$ bupivacaine $(1 \mathrm{ml} / \mathrm{kg})$ improved the analgesic duration and efficacy after a single shot caudal block with minimal side effects in children.

Keywords: Caudal; bupivacaine; clonidine, children.

Corresponding Author: Dr. P.V. Margi, Associate Professor, Department of Anesthesia, Gadag Institute of Medical Sciences, Gadag, India. Email: drmahiv@gmail.com

Received: January 2020

Accepted: January 2020

\section{Introduction}

Pain management is an essential component of care provided by paediatric anaesthesiologists. Most obvious, of course, is the integration of a pain management plan into the overall peri-operative plan. For many years, it has been recognized that paediatric patients are more likely to have pain treated less aggressively than their adult counterparts. ${ }^{[1-3]}$ Unfortunately, one can argue that this has led to a considerable amount of unnecessary suffering on the part of these patients.

It is important to understand that pain due to surgical procedures not only results in an immediate nociceptive response but also results in changes in the nociceptive activation pathways that lead to hypersensitivity, hyperalgesia, and allodynia. ${ }^{[4]}$

Regional anaesthetic techniques reduce the overall intraoperative requirement of both inhaled and intravenous anaesthetic agents and allow more rapid return of the conscious pre-operative state while providing effective postoperative pain relief with minimal sedation. ${ }^{[5]}$

Caudal analgesia is one of the most popular regional anaesthetic technique employed in children. It is a relatively simple technique with a predictable level of blockade, and is by far the most common regional technique used in paediatric surgery for lower abdominal, urological, and lower limb operations. Gradual offset usually provides analgesia beyond the duration of surgery, with a smooth recovery period and good postoperative pain control. This benefit is especially important in ambulatory and same-day surgery patients because it reduces analgesic requirements and facilitates early discharge. ${ }^{[6]}$

However, the mean duration of surgical analgesia provided by single shot caudal procedure is limited by the duration of action of local anaesthetics. Since then various methods have been devised to prolong the duration of action of single shot caudal block. 1:200,000 epinephrine added to local anaesthetic prolongs the analgesic effects of lignocaine, but it seems to have little effect on the longer-acting bupivacaine. ${ }^{[6,7]}$ The addition of opioids also prolongs analgesia but carries with it the risk of respiratory depression. ${ }^{[8]}$ Ketamine produces analgesia after epidural administration and improves the duration and quality of analgesia provided by bupivacaine in caudal blocks (E\&9); however, the potential for neurotoxic effects after inadvertent intrathecal administration limits its application. ${ }^{[9]}$

Clonidine, an alpha 2-adrenergic agonist, produces analgesia without significant respiratory depression after systemic, epidural, or intrathecal administration. Analgesic effect of clonidine is more pronounced after neuraxial injection, which suggests a spinal site of action and makes this route of 
administration preferable. The addition of clonidine also prolongs the duration of action of bupivacaine after intrathecal and epidural administration in adults.10 In children, a mixture of $1 \mathrm{ml} / \mathrm{kg} \quad 0.25 \%$ bupivacaine and 1$2 \mathrm{mcg} / \mathrm{kg}$ clonidine improves the duration and quality of analgesia provided by caudal block, although results differ widely, ranging from 16.4 hours for $1 \mathrm{mcg} / \mathrm{kg}$ to 5.8 and 9.8 hours for $2 \mathrm{mcg} / \mathrm{kg}$. ${ }^{[6]}$

This clinical study is therefore undertaken to compare caudal bupivacaine with clonidine and bupivacaine alone with regards to hemodynamic changes, analgesic potency and side effects in children.

\section{Subjects and Methods}

This study was conducted at Chigateri General Hospital and Bapuji Hospital attached to J.J.M Medical College, Davangere from December 2008 to July 2010.

This study included 60 children, of either sex, coming for various elective infraumbilical surgical procedures such as herniotomies, circumcision, orchidopexy, perineal surgeries and minor lower extremity procedures.

\section{Inclusion criteria:}

Age group of 5-10 yrs

ASA grade I and II

Patients coming for elective infraumbilical surgeries

\section{Exclusion criteria:}

\section{ASA grade III and IV}

Infection at the site of injection

Coagulopathy or anticoagulation

Congenital abnormalities of lower spine and meninges

Active disease of the CNS

History of allergy to local anaesthetics

This study was approved by the Ethics and Standards committee of this institution. Informed consent was obtained from the parent before including the children in the study.

\section{Methods: \\ Pre-anesthetic assessment:}

All patients were visited on the pre-operative day and a detailed general physical examination, systemic examination including airway and spine examination was done. Baseline parameters like heart rate, blood pressure and respiratory rates were noted. Laboratory investigations like routine blood and urine examinations, bleeding time and clotting time, chest x-ray if required, HIV and $\mathrm{HBsAg}$ were done in all patients. Informed consent was obtained from the parent.

\section{Pre-operative fasting:}

Solid foods were restricted for 6 hours, milk for 4-5 hours and clear fluids for 2-3 hours prior to surgery.

\section{Pre-medication:}

All patients were pre-medicated with syrup Promethazine 1 $\mathrm{mg} / \mathrm{kg}$, once on the night before the surgery and another dose in the morning, 1 hour prior to surgery.

\section{Procedure:}

Patients were induced with oxygen, nitrous oxide (50:50) and halothane (in increasing concentration) using Jackson Reis circuit and intravenous line was secured. Injection atropine $0.02 \mathrm{mg} / \mathrm{kg}$ was given intravenously after securing IV access. An infusion of Ringer Lactate was started and fluid was administered according to the calculated requirements.

\section{Caudal block:}

Patient is now gently placed in the left lateral Sim's position, the vitals were checked again including adequacy of spontaneous breathing. Under strict aseptic conditions, sacral hiatus was identified by running the thumb up from coccyx towards the sacrum.

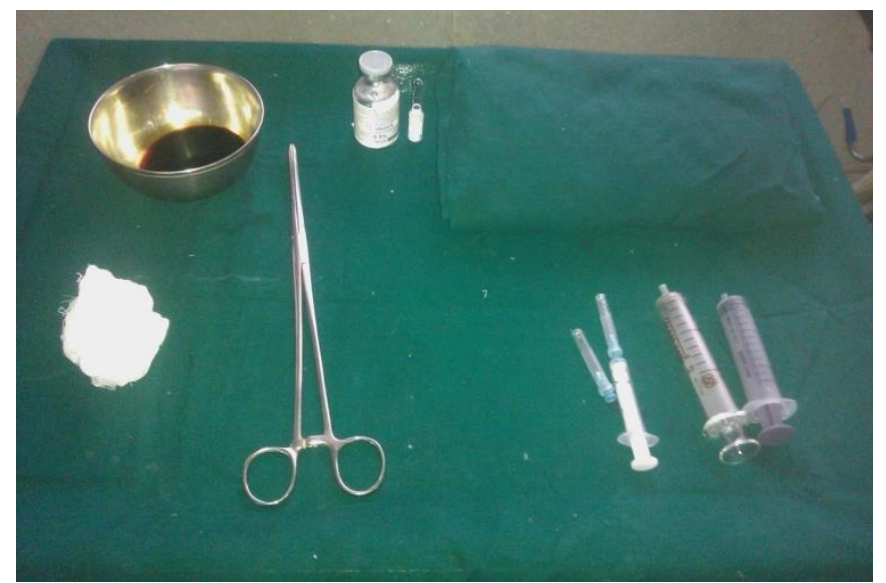

Figure 1: Armamentarium for caudal anaesthesia

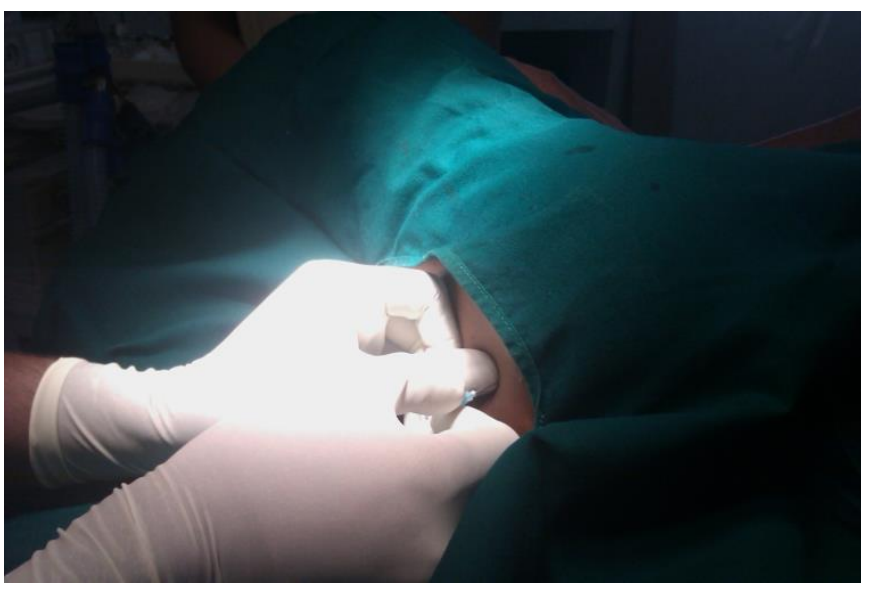

Figure 2: Caudal anaesthesia technique

After identifying the sacral hiatus, a $23 \mathrm{G}$ hypodermic needle with its bevel facing anteriorly was inserted at an angle of $60-70^{\circ}$ to the skin till the sacro-coccygeal membrane was pierced, when a distinct "pop" was felt. The needle is now lowered to an angle of $20^{\circ}$ and advanced 2-3 $\mathrm{mm}$ to make sure that the entire bevel is inside the space. Confirmation of the needle point being in the epidural space was done with the "whoosh" test and the lack of resistance encountered by injection of 2-3 $\mathrm{ml}$ of air. Aspiration was done to exclude dural puncture or vessel puncture and the drug was injected. After injection was complete, the needle was removed and the child was placed in supine position. No analgesia was given by any route pre-operatively or intra- operatively. Anaesthesia was maintained with oxygen, nitrous oxide and halothane $(0.5-2 \%)$ through a face mask with patient on 
spontaneous ventilation throughout the surgery.

\section{Drug and dosage:}

The patients were randomly divided into 2 groups of 30 each. Group A received $0.25 \%$ of bupivacaine $1 \mathrm{ml} / \mathrm{kg}$.

Group B received $0.25 \%$ of bupivacaine $1 \mathrm{ml} / \mathrm{kg}$ with clonidine $1.5 \mu \mathrm{g} / \mathrm{kg}$.

\section{Monitoring:}

Monitoring included precordial stethoscope, pulse-oximetry, NIBP, respiratory rate and ECG. The time of caudal block and duration of surgery was noted.

\section{Recovery:}

Anaesthetic agents were discontinued at the beginning of skin closure. $100 \%$ oxygen through a face mask was administered for 3-5 minutes. Once the vitals were stable and the child was awake, the child was shifted and placed in semi-prone position in the recovery room. On arrival to the recovery room, the child was monitored for another 1 hour with $\mathrm{SpO} 2$, respiratory rate, NIBP and heart rate every 15 minutes. After that the child was shifted to the ward and monitored thereafter.

\section{Parameters studied:}

\section{Hemodynamic parameters:}

Patients were monitored for heart rate, respiratory rate and blood pressure after administration of caudal block at $0,5,15,30,45,60,120$ and 180 minutes and the values were recorded.

\section{Duration of action:}

Duration of action of drug is defined as the time interval between the administration of caudal block and the first requirement of supplementary analgesia for the patient. Postoperative analgesia:

Post-operative analgesia is assessed by Paediatric Objective Pain Scale. The assessment was done for a period of 24 hours after caudal block. If the pain score was more than 6 for 2 consecutive intervals of 10 minutes, then supplementary analgesia with rectal Paracetamol $(15 \mathrm{mg} / \mathrm{kg})$ was given. These assessments were made at 1,2,3,4,8,12 and 24 hours after caudal block.

\section{Side effects:}

Patients were monitored for intra-operative and postoperative complications.

\section{Statistical analysis:}

The results of continuous variables are given as mean \pm SD and proportion as percentage. The difference between the two groups was assessed by student's - $t$ test and chi-square test. For all the tests a 'p' value of 0.05 and less was considered for statistical significance.

\section{Results}

A total number of 60 children in the age group of $5-10$ years belonging to ASA grade I and II were enrolled in this study. They were divided into two groups of 30 each.
Children in group A received caudal bupivacaine $0.25 \%$ $(1 \mathrm{ml} / \mathrm{kg})$

Children in group B received caudal bupivacaine $0.25 \%$ $(1 \mathrm{ml} / \mathrm{kg})$ with clonidine $(1.5 \mu \mathrm{g} / \mathrm{kg})$.

Table 1: Basic characteristics

\begin{tabular}{|l|l|l|l|}
\hline Characteristics & Group A & Group B & p-value \\
\hline Age (years) & $7.1 \pm 1.58$ & $6.86 \pm 1.6$ & 0.94 \\
\hline Gender (M/F) & $\begin{array}{l}26(87) / 4 \\
(13)\end{array}$ & $28(93) / 2(7)$ & 0.39 \\
\hline Weight $(\mathrm{kg})$ & $16.3 \pm 2.9$ & $15.7 \pm 3.4$ & 0.46 \\
\hline
\end{tabular}

The mean age in group A was $7.1 \pm 1.58$ years and in group was $6.86 \pm 1.6$ years. The two groups did not differ significantly $(\mathrm{p}=0.94)$ with respect to their age.

In group A there were $26(87 \%)$ males and $4(13 \%)$ females. Group B had $28(93 \%)$ males and $2(7 \%)$ females. The groups were comparable with respect to sex.

The weight of the children in group A ranged from 12 to 22 $\mathrm{kg}$ with a mean weight of $16.3 \pm 2.9 \mathrm{~kg}$. In group B the weight ranged from 10 to $23 \mathrm{~kg}$ with a mean of $15.7 \pm 3.4$ $\mathrm{kg}$. The two groups did not differ significantly with respect to weight $(\mathrm{p}=0.46)$.

Table 2: Types of Surgical Procedures

\begin{tabular}{|l|l|l|}
\hline & Group A & Group B \\
\hline Types of surgery & $\mathbf{n}(\boldsymbol{\%})$ & $\mathbf{n}(\boldsymbol{\%})$ \\
\hline Circumcision & $6(20)$ & $8(26)$ \\
\hline Herniotomy & $13(43)$ & $14(46)$ \\
\hline Orchidopexy & $2(7)$ & $2(7)$ \\
\hline Anorectal surgeries & $5(16)$ & $4(14)$ \\
\hline Others & $4(14)$ & $2(7)$ \\
\hline
\end{tabular}

The different surgical procedures performed during the study in the two groups are shown in table 6 and graph 4. In our study, herniotomy accounted for around $50 \%$ of cases, 13 $(43 \%)$ in group A and $14(46 \%)$ in group B. Circumcision was done in $6(20 \%)$ and $8(26 \%)$ cases in group A and B respectively, while orchidopexy accounted for 2(7\%) cases in both the groups. Anorectal surgeries like rectal biopsy, polyp excision, proctoplasty and fistula repair were done in $5(16 \%)$ and $4(14 \%)$ in group A and B respectively. Other surgeries included dermoid excision, hemangioma excision and popliteal cyst excision which accounted for $4(14 \%)$ in group A and 2(7\%) in group B.

Table 3: Changes In Heart Rate (Mean \pm SD)
\begin{tabular}{|l|l|l|l|l|l|}
\hline $\begin{array}{l}\text { Time } \\
\text { interval } \\
\text { (min) }\end{array}$ & $\begin{array}{l}\text { Group } \\
\text { A }\end{array}$ & $\begin{array}{l}\text { Group } \\
\text { B }\end{array}$ & $\begin{array}{l}\text { Mean } \\
\text { Difference }\end{array}$ & $\begin{array}{l}\mathbf{P}^{*} \\
\text { Value }\end{array}$ & Significance \\
\hline Baseline & $89 \pm 5.6$ & $91 \pm 8.6$ & 1.1 & 0.48 & NS \\
\hline 0 & $94 \pm 5.2$ & $93 \pm 7.1$ & 1.2 & 0.42 & NS \\
\hline 5 & $98 \pm 6.4$ & $96 \pm 6.1$ & 1.5 & 0.32 & NS \\
\hline 15 & $98 \pm 5.2$ & $97 \pm 5.3$ & 1.0 & 0.52 & NS \\
\hline 30 & $90 \pm 6.3$ & $93 \pm 6.0$ & 2.1 & 0.15 & NS \\
\hline 45 & $89 \pm 5.7$ & $91 \pm 5.6$ & 1.6 & 0.37 & NS \\
\hline 60 & $87 \pm 5.9$ & $88 \pm 7.8$ & 1.6 & 0.37 & NS \\
\hline 120 & $86 \pm 5.9$ & $88 \pm 6.5$ & 1.7 & 0.32 & NS \\
\hline 180 & $87 \pm 6.3$ & $88 \pm 6.6$ & 1.0 & 0.52 & NS \\
\hline
\end{tabular}

In group $A$, the mean baseline heart rate was $89 \pm 5.6$ per minute which increased to $98 \pm 6.4$ at $5 \mathrm{~min}$. The heart rate gradually decreased to $87 \pm 6.3$ per minute at 180 minutes. The mean baseline heart rate in group B was $91 \pm 8.6$ per 
minute which increased to $97 \pm 5.3$ at 15 minutes and gradually decreased to $88 \pm 7$ at $60 \mathrm{~min}$ and remained so till 180 minutes.

However, there was no significant difference in the heart rate between the two groups at any time interval ( $\mathrm{p}>0.05)$.

\begin{tabular}{|c|c|c|c|c|c|}
\hline $\begin{array}{l}\text { Time } \\
\text { interval } \\
\text { (min) }\end{array}$ & Aroup & $\begin{array}{l}\text { Group } \\
\text { B }\end{array}$ & $\begin{array}{l}\text { Mean } \\
\text { Difference }\end{array}$ & $\begin{array}{l}\text { P* } \\
\text { Value }\end{array}$ & Significance \\
\hline Baseline & $\begin{array}{l}98 \pm \\
7.4\end{array}$ & $\begin{array}{l}100 \pm \\
6.9\end{array}$ & 1.57 & 0.40 & NS \\
\hline 0 & $\begin{array}{l}99 \pm \\
7.0\end{array}$ & $\begin{array}{l}101 \pm \\
6.9\end{array}$ & 2.00 & 0.27 & NS \\
\hline 5 & $\begin{array}{l}107 \pm \\
7.7\end{array}$ & $\begin{array}{l}105 \pm \\
6.0\end{array}$ & 1.93 & 0.28 & NS \\
\hline 15 & $\begin{array}{l}104 \pm \\
8.4\end{array}$ & $\begin{array}{l}103 \pm \\
4.6\end{array}$ & 1.20 & 0.49 & NS \\
\hline 30 & $\begin{array}{l}100 \pm \\
7.0\end{array}$ & $\begin{array}{l}101 \pm \\
3.3\end{array}$ & 1.73 & 0.22 & NS \\
\hline 45 & $\begin{array}{l}97 \pm \\
7.03\end{array}$ & $\begin{array}{l}99 \pm \\
2.7\end{array}$ & 1.20 & 0.39 & NS \\
\hline 60 & $\begin{array}{l}96 \pm \\
7.2\end{array}$ & $\begin{array}{l}97 \pm \\
3.7\end{array}$ & 0.13 & 0.93 & NS \\
\hline 120 & $\begin{array}{l}94 \pm \\
6.7\end{array}$ & $\begin{array}{l}96 \pm \\
3.0\end{array}$ & 0.93 & 0.49 & NS \\
\hline 180 & $\begin{array}{l}97 \pm \\
9.1\end{array}$ & $\begin{array}{l}96 \pm \\
3.3\end{array}$ & 1.33 & 0.29 & NS \\
\hline
\end{tabular}

The mean baseline systolic blood pressure was $98 \pm 7.4 \mathrm{~mm}$ $\mathrm{Hg}$ in group A. It increased to $107 \pm 7.7 \mathrm{~mm} \mathrm{Hg}$ at $5 \mathrm{~min}$ and then gradually decreased to $97 \pm 9.1 \mathrm{~mm} \mathrm{Hg}$ at 180 minutes. In group $\mathrm{B}$, the mean baseline systolic blood pressure was $100 \pm 6.9 \mathrm{~mm} \mathrm{Hg}$, which increased to $105 \pm 6 \mathrm{~mm} \mathrm{Hg}$ at 5 minutes and then gradually decreased to $96 \pm 3.3 \mathrm{~mm} \mathrm{Hg}$ at 180 minutes.

At all time interval, the $\mathrm{p}$ value was $>0.05$ and hence the differences in the systolic blood pressure were insignificant at all time intervals.

\begin{tabular}{|c|c|c|c|c|c|}
\hline $\begin{array}{l}\text { Time } \\
\text { interval } \\
\text { (min) }\end{array}$ & $\begin{array}{l}\text { Group } \\
\text { A }\end{array}$ & $\begin{array}{l}\text { Group } \\
\text { B }\end{array}$ & $\begin{array}{l}\text { Mean } \\
\text { Difference }\end{array}$ & $\begin{array}{l}\text { P* } \\
\text { Value }\end{array}$ & Significance \\
\hline Baseline & $63 \pm 4.8$ & $\begin{array}{l}63 \pm \\
6.9\end{array}$ & 0.07 & 0.97 & NS \\
\hline 0 & $63 \pm 4.8$ & $\begin{array}{l}63 \pm \\
6.8\end{array}$ & 0.073 & 0.98 & NS \\
\hline 5 & $69 \pm 4.8$ & $\begin{array}{l}67 \pm \\
6.7 \\
\end{array}$ & 2.33 & 0.13 & NS \\
\hline 15 & $69 \pm 5.4$ & $\begin{array}{l}68 \pm \\
4.0\end{array}$ & 0.93 & 0.53 & NS \\
\hline 30 & $63 \pm 5.9$ & $\begin{array}{l}65 \pm \\
6.3\end{array}$ & 2.13 & 0.18 & NS \\
\hline 45 & $63 \pm 6.1$ & $\begin{array}{l}64 \pm \\
6.3\end{array}$ & 0.87 & 0.59 & NS \\
\hline 60 & $61 \pm 6.2$ & $\begin{array}{l}60 \pm \\
7.1\end{array}$ & 1.13 & 0.51 & NS \\
\hline 120 & $60 \pm 5.0$ & $\begin{array}{l}61 \pm \\
6.6\end{array}$ & 1.33 & 0.38 & NS \\
\hline 180 & $60 \pm 5.8$ & $\begin{array}{l}62 \pm \\
6.6\end{array}$ & 1.87 & 0.25 & NS \\
\hline
\end{tabular}

The mean baseline diastolic blood pressure in group A was $63 \pm 4.8 \mathrm{~mm} \mathrm{Hg}$ which increased to a maximum of $69 \pm 4.8$ $\mathrm{mm} \mathrm{Hg}$ at 5 minutes and gradually decreased to $60 \pm 5.8 \mathrm{~mm}$ $\mathrm{Hg}$ at 180 minutes. In group B the mean baseline diastolic blood pressure was $63 \pm 6.9 \mathrm{~mm} \mathrm{Hg}$, increased to $68 \pm 4 \mathrm{~mm}$
$\mathrm{Hg}$ at 15 minutes and progressively declined to $62 \pm 6.6 \mathrm{~mm}$ $\mathrm{Hg}$ at 180 minutes. There was no significant difference in the diastolic blood pressure $(p>0.05)$ at any of the time intervals.

Table 6: Changes in Respiratory Rate (Mean \pm SD)

\begin{tabular}{|l|l|l|l|l|l|}
\hline $\begin{array}{l}\text { Time } \\
\text { interval } \\
\text { (min) }\end{array}$ & $\begin{array}{l}\text { Group } \\
\text { A }\end{array}$ & $\begin{array}{l}\text { Group } \\
\text { B }\end{array}$ & $\begin{array}{l}\text { Mean } \\
\text { Difference }\end{array}$ & $\begin{array}{l}\text { P* } \\
\text { Value }\end{array}$ & $\begin{array}{l}\text { Significa } \\
\text { nce }\end{array}$ \\
\hline Baseline & $26 \pm 2.1$ & $27 \pm 3.5$ & 0.93 & 0.21 & NS \\
\hline 0 & $27 \pm 2.2$ & $27 \pm 3.2$ & 0.23 & 0.74 & NS \\
\hline 5 & $31 \pm 3.3$ & $30 \pm 4.1$ & 0.73 & 0.42 & NS \\
\hline 15 & $31 \pm 3.3$ & $31 \pm 3.6$ & 0.37 & 0.71 & NS \\
\hline 30 & $26 \pm 2.8$ & $27 \pm 3.6$ & 0.87 & 0.30 & NS \\
\hline 45 & $26 \pm 3.0$ & $25 \pm 3.1$ & 0.60 & 0.45 & NS \\
\hline 60 & $25 \pm 2.6$ & $24 \pm 3.0$ & 0.86 & 0.20 & NS \\
\hline 120 & $23 \pm 2.6$ & $24 \pm 3.1$ & 0.93 & 0.21 & NS \\
\hline 180 & $24 \pm 3.3$ & $23 \pm 3.4$ & 0.30 & 0.70 & NS \\
\hline
\end{tabular}

In group $A$ the mean baseline respiratory rate was $26 \pm 2.1$ per min, which increased to $31 \pm 3.3$ per min at $15 \mathrm{~min}$ and gradually decreased to $24 \pm 3.3$ per $\min$ at $180 \mathrm{~min}$. The mean baseline respiratory rate in group B was $27 \pm 3.5$ per min which increased to $31 \pm 3.6$ per min at $15 \mathrm{~min}$ and reduced to $23 \pm 3.4$ per $\min$ at $180 \mathrm{~min}$.

The difference in the respiratory rate between the two groups was statistically not significant $(\mathrm{p}>0.05)$ at any time interval.

Table 7: Pain Score at Various Time Intervals
\begin{tabular}{|l|l|l|l|l|}
\hline $\begin{array}{l}\text { Time } \\
\text { interval } \\
\text { (hours) }\end{array}$ & $\begin{array}{l}\text { Group A } \\
\mathbf{n}(\%)\end{array}$ & $\begin{array}{l}\text { Group B } \\
\mathbf{n}(\%)\end{array}$ & $\mathbf{P}^{*}$ Value & $\mathbf{T}^{\mathbf{2}}$ value \\
\hline 1 & 0 & 0 & - & - \\
\hline 2 & 0 & 0 & - & - \\
\hline 3 & $1(3)$ & 0 & 1 & 0 \\
\hline 4 & $14(47)$ & $1(3)$ & $<0.01$ & 12.8 \\
\hline 8 & $13(43)$ & $19(63)$ & 0.2 & 1.6 \\
\hline 12 & $9(30)$ & $9(30)$ & - & - \\
\hline 24 & $13(43)$ & $11(33)$ & 0.8 & 0.06 \\
\hline
\end{tabular}

The distribution of subjects in the two study groups according to pain score $>=6$ at various monitoring intervals as shown in Table 7. The Paediatric Objective Pain Score was below 6 at the end of first and second hour in both the groups and did not require any analgesia.

At the end of third hour, 1(3\%) of the patients in group A had a pain score of statistically insignificant $(\mathrm{p}>0.05)$.

At the end of fourth hour, 14(47\%) of patients in group A had a pain score of significant $(\mathrm{p}<0.01)$.

The pain score was 6 in 13(43\%) of patients in group A and $19(63 \%)$ in group B by the end of eight hour which was not statistically significant.

At the end of 12th and 24th hour, group A had 9(30\%) and $13(43 \%)$ patients with pain score of $>=6$ and group B had $9(30 \%)$ and $11(33 \%)$ with similar pain score respectively. The differences were found statistically insignificant.

The subjects with a pain score of $>=6$ were significantly lower in group B compared to group A at the end of 3rd and 4th hour.

Table 8: Duration of Analgesia

\begin{tabular}{|l|l|l|}
\hline $\begin{array}{l}\text { Duration of } \\
\text { analgesia (min) }\end{array}$ & Group A & Group B \\
\hline Mean duration \pm SD & $250.33 \pm 41.4$ & $433.5 \pm 60.2$ \\
\hline Range & $180-355$ & $265-530$ \\
\hline$p<0.01$, student's unpaired 't' test
\end{tabular}


The mean duration of analgesia was $250.33 \pm 41.4 \mathrm{~min}$ in group A with a range of 180 to $355 \mathrm{~min}$. In group $\mathrm{B}$, the mean duration of analgesia was $433.5 \pm 60.2$ min with a range of 265 to $530 \mathrm{~min}$. The difference in the mean duration of analgesia was statistically highly significant $(\mathrm{p}<0.001)$.

\begin{tabular}{|l|l|l|l|l|}
\hline Table 9: Sedation Score at Various Time Intervals \\
\hline $\begin{array}{l}\text { Time } \\
\text { interval } \\
\text { (hours) }\end{array}$ & $\begin{array}{l}\text { Group A } \\
\mathbf{n}(\%)\end{array}$ & $\begin{array}{l}\text { Group B } \\
\mathbf{n}(\%)\end{array}$ & $\mathbf{p}^{*}$ value & $\begin{array}{l}\mathbf{T}^{\mathbf{2}} \\
\text { value }\end{array}$ \\
\hline 1 & $30(100)$ & $30(100)$ & - & - \\
\hline 2 & $30(100)$ & $30(100)$ & - & - \\
\hline 3 & $30(100)$ & $30(100)$ & - & - \\
\hline 4 & $9(30)$ & $29(97)$ & $<0.001$ & 25.9 \\
\hline 8 & 0 & $14(46)$ & $<0.01$ & 15.7 \\
\hline 12 & 0 & $2(6)$ & 0.47 & 0.51 \\
\hline 24 & 0 & 0 & - & - \\
\hline
\end{tabular}

The distribution of subjects in the two study groups according to sedation score $<=3$ at various monitoring interval are shown in Table 9.

The sedation score at the end of first, second and third hour was less than 3 in both the groups and the children were drowsy but responding to verbal commands.

At the end of fourth and eight hour $9(30 \%)$ and $0(0 \%)$ of patients in group A and 29(97\%) and 14(46\%) of patients in group B respectively had a score of 3 , indicating a significant difference in the sedation score between the groups at that time.

At the end of $12^{\text {th }}$ and $24^{\text {th }}$ hour, all the patients in group A were awake and alert. In group B 2(6\%) had a score of 3 at the 12th hour and all were awake by the end of 24th hour. There was no significant difference between the two groups at this time.

The incidence of nausea and vomiting was among 3(9\%) children in group A compared to $2(6 \%)$ in group B. This was not statistically significant. There was no incidence of hypotension, bradycardia, dural or vessel puncture and respiratory depression in the two groups.

\section{Discussion}

\section{Age, sex and weight:}

In the present study, there was no significant difference in the two groups with regard to age, weight and sex.

The mean age was $7.1 \pm 1.6$ years in group $A$ and $6.86 \pm 1.6$ years in group B. The mean weight was $16.3 \pm 2.9 \mathrm{~kg}$ in group $\mathrm{A}$ and $15.7 \pm 3.4 \mathrm{~kg}$ in group $\mathrm{B}$. In both the groups males were more $(>80 \%)$. This could be due to inclusion of surgeries like herniotomy, orchidopexy and circumcision in our study. Cook et al10 studied the effect of caudal analgesia in paediatric patients in the age group of 1-10 years, undergoing only orchidopexy, hence all the cases were male $(100 \%)$.

\section{Concentration and dosage of the drug:}

Gunter JB et al have reported that $0.175 \%$ bupivacaine offered the best combination of effectiveness and rapid recovery and discharge for paediatric surgical outpatients. ${ }^{[1]}$ Armitage has recommended $0.25 \%$ bupivacaine in a dose of $0.5 \mathrm{ml} / \mathrm{kg}$ lumbo- sacral, $1 \mathrm{ml} / \mathrm{kg}$ for thoraco-lumbar 1.25 $\mathrm{ml} / \mathrm{kg}$ for mid-thoracic level of block and the plasma bupivacaine levels were always below $1.2 \mu \mathrm{g} / \mathrm{ml}$, which was below toxic levels. ${ }^{[12]}$ However, Jamali $S$ et al, ${ }^{[13]}$ and Cook B et al9 used $0.25 \%$ bupivacaine $(1 \mathrm{ml} / \mathrm{kg})$ for paediatric herniotomy and orchidopexy respectively, as a single shot caudal block.

In our study also, we have used a single dose of $0.25 \%$ bupivacaine $(1 \mathrm{ml} / \mathrm{kg})$. Higher concentration can produce motor blockade in the immediate post-operative period and delay discharge. Since all the patients are monitored for 24 hours post- operatively in our hospital, $0.25 \%$ bupivacaine was used for post-operative analgesia.

Jamali $\mathrm{S}$ and colleagues found that the mean duration of post-operative analgesia with caudal bupivacaine $0.25 \%$ $(1 \mathrm{ml} / \mathrm{kg})$ was significantly increased by addition of clonidine $1 \mu \mathrm{g} / \mathrm{kg}$ compared with plain bupivacaine or bupivacaine with epinephrine $5 \mu \mathrm{g} / \mathrm{ml}^{[13]}$

Cook B et al, ${ }^{[9]}$ and Lee JJ et al, ${ }^{[14]}$ used clonidine $(2 \mu \mathrm{g} / \mathrm{kg})$ with bupivacaine $0.25 \%(1 \mathrm{ml} / \mathrm{kg})$ caudally in children aged 1 to 10 years for orchidopexy and orthopaedic surgery respectively.

Klimscha and colleagues demonstrated that in small children (mean age 3 yrs) undergoing daycase hernia repair, the addition of clonidine 1 or $2 \mu \mathrm{g} / \mathrm{kg}$ to bupivacaine $0.25 \%$ $(0.75 \mathrm{ml} / \mathrm{kg})$ significantly prolonged the mean duration of analgesia and reduced the post-operative analgesic requirement within the first 24 hours. The analgesic effects were similar in both the groups, although the relatively low level of pain associated with inguinal herniotomy may have made it difficult to separate the analgesic efficacy of the two doses. $^{[15]}$

Motsch and colleagues found that clonidine $5 \mu \mathrm{g} / \mathrm{kg}$ significantly prolonged caudal block with bupivacaine $0.175 \%(1 \mathrm{ml} / \mathrm{kg})$ in children aged $4-8$ years undergoing minor surgery. ${ }^{[16]}$

In our study, we chose $0.25 \%$ bupivacaine which provides better quality of analgesia when compared to lower concentrations and clonidine $1.5 \mu \mathrm{g} / \mathrm{kg}$ which prolongs the duration of analgesia significantly while avoiding the side effects like excessive sedation and bradycardia associated with higher doses.

\section{Changes in hemodynamic parameters:}

In the present study, mean baseline heart rate was similar in both groups. The mean baseline rate was $89 \pm 5.6$ per minute in group A and $91 \pm 8.6$ per min in group B. Initially there was a rise in heart rates to $98 \pm 6.4$ and $97 \pm 5.3$ per minute respectively in both the groups. This might be attributed to the premedication with atropine and the surgical procedure itself. On commencement of action of caudal block, there was a decrease in heart rate in both the groups which gradually reached baseline. The mean heart rate was $87 \pm 6.3$ in group $\mathrm{A}$ and $88 \pm 6.6$ in group $\mathrm{B}$ at 180 minutes. There was no significant difference in the heart rates between the two groups at any time interval.

Similarly, there was no significant difference in the blood pressure between the two groups at any time interval. The mean baseline systolic blood pressure was $98.87 \pm 7.4 \mathrm{~mm}$ $\mathrm{Hg}$ in group $\mathrm{A}$ and $100 \pm 6.9 \mathrm{~mm} \mathrm{Hg}$ in group B. After an initial rise at 5 minutes, there was a gradual fall in the systolic blood pressure to $97 \pm 9.1 \mathrm{~mm} \mathrm{Hg}$ and $96 \pm 3.3 \mathrm{~mm}$ $\mathrm{Hg}$ at 180 minutes in group A and B respectively which was 
only $2 \%$ and $4 \%$ below the baseline.

The mean baseline diastolic blood pressure was $63 \pm 4.8 \mathrm{~mm}$ $\mathrm{Hg}$ in group $\mathrm{A}$ and $63 \pm 6.9 \mathrm{~mm} \mathrm{Hg}$ in group B. It gradually decreased to $60 \pm 5$ and $62 \pm 6.5 \mathrm{~mm} \mathrm{Hg}$ at $180 \mathrm{~min}$ after an initial rise at 5 minutes which could be due to surgical procedure itself.

There was no incidence of bradycardia or hypotension in both the groups. Jamali $\mathrm{S}$ et $\mathrm{al},{ }^{[13]}$ and $\mathrm{JJ}$ Lee et al, ${ }^{[14]}$ reported the lowest systolic pressure values $1-2$ hours after caudal injection (mean maximum decrease of $6.5 \%$ ). Hemodynamic changes appear to be less pronounced in children than in adults.

Motsch and colleagues, ${ }^{[16]}$ found that children receiving high dose clonidine $(5 \mu \mathrm{g} / \mathrm{kg})$ had lower systolic pressures and heart rate during the first 3 hours after surgery compared with the control group. However, apart from one of the 20 children who received atropine to treat a heart rate of less than 70 beats per minute, no additional measures were necessary with this relatively high dose clonidine.

\section{Changes in respiratory parameters:}

In the present study, no significant difference in the respiratory rate between the two groups was observed. There were no cases of respiratory depression in patients of either group as evidenced by a fall in the respiratory rate of less than 10 breaths per minute or a fall in the oxygen saturation of less than $90 \%$.

Penon and colleagues, ${ }^{[17]}$ reported a slight decrease in the slope of carbon dioxide response curve following the epidural administration of clonidine $300 \mu \mathrm{g}$ in healthy adult volunteers.

Narchi P et al, ${ }^{[18]}$ conducted a study on ventilatory effects of clonidine after Caesarean section and found no significant respiratory depression with $150 \mu \mathrm{g}$ of clonidine but $300 \mu \mathrm{g}$ of clonidine was frequently associated with marked sedation, obstructive apnoea and arterial oxygen desaturation.

Breschan C et al, ${ }^{[19]}$ reported a case of life-threatening apnoea following herniorraphy and orchidopexy in a 2 week old term neonate.

No such respiratory depressant effects of clonidine were observed in our study.

\section{Post-operative analgesia:}

In our study, we have used Pediatric Objective Pain scale which is a valid, objective and reliable method of pain assessment in children between 5 to 10 years.

There was no incidence of pain score pain score $>-6$ at the end of 1 st and 2 nd hour. $1^{\text {st }}$ and $2^{\text {nd }}$ hour in either groups. At the end of $3^{\text {rd }}$ hour, $1(3 \%)$ of children in group A and none of the children in group B had a pain score of $\bullet$ pain score of $>=6$. At the end of 4th hour, 14(46\%) of children in group A and only $1(3 \%)$ of children in group B had pain score $>6$, which is highly significant. The difference was not significant between the 2 groups in the remaining time interval with regards to analgesic efficacy.

The duration of analgesia was significantly prolonged in bupivacaine-clonidine group $(433.5 \pm 60.2 \mathrm{~min})$ compared to bupivacaine alone group $(250.33 \pm 41.4 \mathrm{~min})$ in our study. This is in agreement with a study by $\mathbf{J} \mathbf{J}$ Lee and colleagues, ${ }^{[14]}$ which found that addition of clonidine to local anaesthetic prolongs the duration of analgesia after a single shot caudal block. They reported an increase in the mean duration of analgesia $(588 \pm 120 \mathrm{~min})$ after the addition of clonidine when compared to local anaesthetic alone (312 \pm $60 \mathrm{~min})$.

Jamali and colleagues, ${ }^{[13]}$ in a study of children aged 1-7 years undergoing sub- umbilical surgery, found that the mean duration of post-operative analgesia was significantly increased on adding clonidine $1 \mu \mathrm{g} / \mathrm{kg}(990 \pm 570 \mathrm{~min})$ to plain bupivacaine $0.25 \%(1 \mathrm{ml} / \mathrm{kg})(460 \pm 420 \mathrm{~min})$.

Cook B et al, ${ }^{[9]}$ confirmed the superiority of caudal clonidine $2 \mu \mathrm{g} / \mathrm{kg}$ over epinephrine $5 \mu \mathrm{g} / \mathrm{ml}$ added to bupivacaine $0.25 \%(1 \mathrm{ml} / \mathrm{kg})$ in a double blind study of boys, 1-10 years of age, undergoing orchidopexy. The mean duration was significantly longer in clonidine group (348 min) compared with those receiving epinephrine (192 min). The duration of analgesia achieved by the addition of clonidine to bupivacaine varies widely in these studies (5.8 16.5 hours). This may be the result of a number of factors: dose of clonidine used; differences in premedication and volatile anaesthetics used; type of surgery; indications for rescue analgesia; assessment of pain and statistical analysis.

However, Joshi $\mathrm{W}$ et al, ${ }^{[20]}$ concluded that there was no significant demographic, hemodynamic, or pain score differences between the groups as well as there was no difference in analgesic duration. This study was conducted in 36 children undergoing elective surgery using bupivacaine $0.125 \%(1 \mathrm{mg} / \mathrm{kg})$ with equal volume of either clonidine $2 \mu \mathrm{g} / \mathrm{kg}$ or saline.

This could be due to small concentration of local anaesthetic used and the use of parental pain scores following discharge from the hospital.

\section{Sedation score:}

In our study, a child with a sedation score of $<=3$ was considered sedated. A score of 4 indicated that the child was completely awake and alert. All the children in group A and B were sedated for a period of 3 hours. 29(97\%) of the children in group B and $9(30 \%)$ in group A were sedated at the end of $4^{\text {th }}$ hour.

There was no significant sedation in the post-operative period leading to respiratory depression. The sedation score was either 2 or more in all the patients at all times. The duration of sedation corresponded closely with the duration of analgesia.

$\mathrm{J} \mathbf{J}$ Lee et al, ${ }^{[14]}$ also found that the duration of sedation was very similar to the respective duration of caudal analgesia in both the groups. None of the children had an $\mathrm{SpO} 2$ value of $<95 \%$ or ventilatory frequency of less than 16 in the postoperative period.

\section{Complications:}

In our study, 3 of the children in group A and 2 of them in group B had an episode of vomiting which was treated with Inj Metaclopramide $(0.1-0.2 \mathrm{mg} / \mathrm{kg}) \mathrm{IV}$. The incidence of vomiting was comparable in both the groups, $9 \%$ and $6 \%$ in group A and B respectively.

The addition of clonidine to bupivacaine in our study, did not result in an increase in the incidence of side effects. The main side-effects of epidurally administered clonidine are bradycardia, hypotension and sedation. In our study, bradycardia or hypotension warranting treatment did not 
occur. Sedation, as mentioned earlier, correlated well with the duration of analgesia.

\section{Conclusion}

The present study demonstrated that caudal administration of bupivacaine $0.25 \% \quad(1 \mathrm{ml} / \mathrm{kg})$ with clonidine $(1.5 \mu \mathrm{g} / \mathrm{kg})$ resulted in superior analgesia with longer duration of action compared with $0.25 \%$ bupivacaine $(1 \mathrm{ml} / \mathrm{kg})$ alone, without any significant difference in the hemodynamic parameters and the incidence of side-effects.

\section{References}

1. Twycross A, Mayfield C, Savory J. Pain management for children with special needs: A neglected area?. Paediatr Nurs 1999; 11:43-45.

2. Sahler O, Frager G, Levetown M, et al. Medical education about end-oflife care in the pediatric setting: Principles, challenges, and opportunities. Pediatrics 2000; 105:575-584.

3. Eland JM. Children's communication of pain. Educational Psychology, Iowa City, University of Iowa, 1974.

4. Anand KJ, Hickey PR. Pain and its effects in the human neonate and fetus. N Engl J Med 1987; 317:1321-1329.

5. Markakis DA. Regional anaesthesia in paediatrics. Anesthesiol Clin North America 2000;18(2):355-9.

6. De-Beer DAH, Thomas ML. Caudal additives in children - solutions or problems? Br J Anaesth 2003;90(4):487-98 .

7. Cook B, Doyle E. The use of additives to local anaesthetic solutions for caudal epidural blockade. Paediatric Anaesth 1996;6:353-9.

8. Valley RD, Bailey AG. Caudal morphine for post-operative analgesia in infants and children: a report of 138 cases. Anaesthesia and Analgesia 1991;72:120-124

9. Cook B, Grubb DJ, Aldridge LA, Doyle E. Comparison of the effects of epinephrine, clonidine and ketamine on the duration of caudal analgesia produced by bupivacaine in children. Br J Anaesth 1995;75:698-701

10. Basker S, Singh G, Jacob R. Clonidine in paediatrics - a review. Indian J Anaesth 2009;53(3):270-280.

11. Gunter JB, Dunn CM, Bennie JB, Pentecost DL, Bower RJ, Ternberg JL. Optimum concentration of bupivacaine for combined caudal-general anaesthesia in children. Anaesthesiology 1991;75(1):57-61.

12. Armitage EN. Caudal block in children. Anaesthesia 1979;34:396.

13. Jamali S, Monin S, Begon C, Dubousset A, Ecoffey C. Clonidine in paediatric caudal anaesthesia. Anaesth Analg 1994;78:663-6.

14. Lee JJ, Rubin AP. Comparison of a bupivacaine-clonidine mixture with plain bupivacaine for caudal analgesia in children. $\mathrm{Br} \mathrm{J}$ Anaesth 1994;72:258-262.

15. Klimscha W, Chiari A, Michalek-Saubere A, Wilding E, Lerche A, Lorber $\mathrm{C}$, et al. The efficacy and safety of caudal clonidine/bupivacaine combination in caudal blockade for pediatric hernia repair. Anesth Analg 1998 Jan;86(1):54-61.

16. Motsch J, Bottiger BW, Bach A, Bohrer H, Skoberne T, Marin E. Caudal clonidine and bupivacaine for combined epidural and general anaesthesia in children. Acta Anaesthesiol Scand 1997;41:877-83.

17. Penon C, Ecoffey C, Cohen SE. Ventilatory response to carbon dioxide after epidural clonidine injection. Anesth Analg 1991;72:761-4.

18. Narchi P, Benhamou D, Hamza J, Bouziz H. Ventilatory effects of epidural clonidine during the first 3 hours after caesarean section. Acta Anaesthesiol Scand 1992;36:791-5.

19. Breschan C, Krumpholz R, Likar R, Kraschl R, Schalk H. Can a dose of $2 \mu \mathrm{g} / \mathrm{kg}$ caudal clonidine cause respiratory depression in neonates? Paediatr Anaesth 1999;9:81-3.

20. Joshi W, Connelly NR, Freeman K, Reuben SS. Analgesic effect of clonidine added to bupivacaine $0.125 \%$ in paediatric caudal blockade. Paediatr Anaesth 2004 Jun;14(6):483-6.

Copyright: (C) the author(s), 2020. It is an open-access article distributed under the terms of the Creative Commons Attribution License (CC BY 4.0), which permits authors to retain ownership of the copyright for their content, and allow anyone to download, reuse, reprint, modify, distribute and/or copy the content as long as the original authors and source are cited.

How to cite this article: Gouda SJ, Margi PV. Comparative Study of Caudal Bupivacaine and Bupivacaine with Clonidine in Infra Umbilical Surgeries in Children. Acad. Anesthesiol. Int. 2020;5(1):23-29.

DOI: dx.doi.org/10.21276/aan.2020.5.1.5

Source of Support: Nil, Conflict of Interest: None declared 